\title{
Die missionale kerk in informele behuisingsgemeenskappe
}

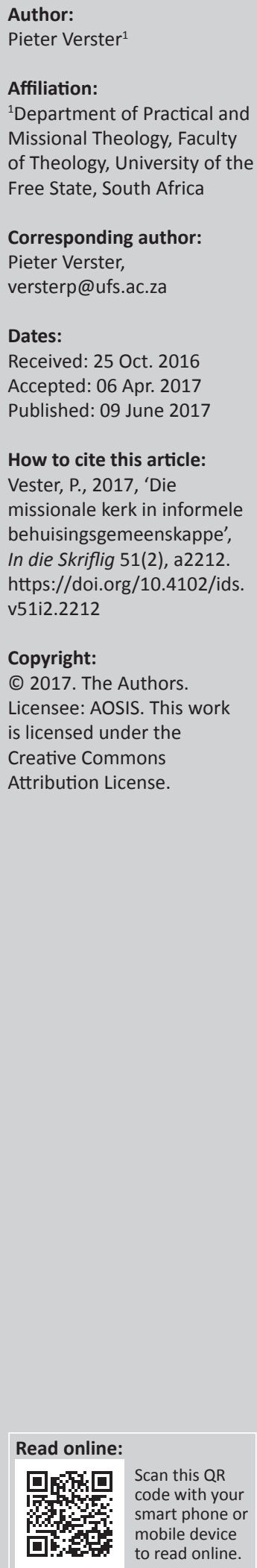

\begin{abstract}
The missional church in communities in informal settlements. Mission in informal settlements faces huge challenges, which include poor living conditions and structures, lack of infrastructure and medical facilities, extreme poverty, illnesses, criminality, youth subcultures, et cetera. Massive urbanisation plays an important role in this regard. From the missio Dei perspective the missional church should view the communities with a holistic approach. Missio Dei means that the living God sends his Son to the world in need so that the church, through the Holy Spirit, can become a mission church. The glory of Jesus Christ is central in the proclamation of this message and transcendence should be acknowledged in mission. The living church will emphasise and live out kerugma, diakonia, marturia, koinonia and leiturgia. Much attention will be given to Christian hope to empower communities who live under dire circumstances. Love and justice will also be emphasised. Only when the missional church becomes a true living church can the full community be served.
\end{abstract}

\section{Inleiding}

Inwoners in informele behuisingsgemeenskappe word daagliks met besondere uitdagings gekonfronteer. Verstedeliking is in hierdie verband van groot belang. Die uitdagings van hierdie gemeenskappe stel besondere groot eise aan die sending. Missio Dei is 'n begrip wat die sending beslissend bepaal, sowel as die gepaardgaande opkoms van die missionale kerk. Die kerk moet ingrypende besluite neem oor die wyse waarop die kerk by die mense in informele behuisingsgebiede betrokke raak. Daar moet dus intensief oor die missio Dei en die missionale kerk nagedink word.

\section{Metodologie en navorsingsvraag}

Om te bepaal hoe die kerk op die uitdagings van die informele gemeenskappe moet reageer, vereis nie net 'n oorsig oor die situasie nie, maar die begrippe missio Dei en missionale kerk moet ook oorweeg word. Voorstelle van hoe die kerk betrokke kan raak, is ook nodig en sluit 'n literatuurstudie en hermeneutiese oorwegings in.

Die sentrale navorsingsvraag is: Kan die missio Dei en die daaropgebaseerde missionale kerk die informele behuisingsgemeenskappe op so 'n wyse bedien dat God se koninkryk ook daar sigbaar word?

\section{Die uitdagings in informele gemeenskappe}

Onbeheersde verstedeliking stel ongelooflike eise aan gemeenskappe en owerhede. Die toestroming vanaf plattelandse gebiede, migrasie, bevolkingsverskuiwings en mensgemaakte en natuurrampe lei tot 'n toename in die stedelike bevolking. Die uitdaging om die invloei van mense te beheer en te hanteer, is buitengewoon groot. Miller (1998:119) toon byvoorbeeld aan hoe die bevolkingsgroei in die wêreld eksponensieel toeneem en dat verstedeliking 'n direkte gevolg daarvan is. Ook in die Suid-Afrikaanse gemeenskap vind verstedeliking op 'n ongeëwenaarde wyse plaas. Dit plaas groot druk op owerhede en gemeenskappe.

Nihinlola (2010:102) bespreek die groot uitdagings vir die kerk in Afrika ten opsigte van die omgewing wat deur armoede, ongeregtigheid, korrupsie, swak regering en gemeenskapskonflikte (etnies, religieus, polities) gekenmerk word. Hierdie uitdagings kom besonder sterk in informele behuisingsgebiede voor. In die meeste van die informele gebiede is die behuising informeel in die sin dat dit nie 'n vaste struktuur of vaste woonplek is nie. Die lewenswyse verander voortdurend. 'n Informele gebied is dikwels nie geproklameer nie, en daar is nie gevestigde dienste nie. Mense uit verskillende gemeenskappe kom bymekaar sonder dat daar ' $n$ vaste struktuur is. 
Hierdie gemeenskappe word soms op 'n nuwe manier aan mekaar gebind. Die gemeenskappe is soekend na die een of ander vaste struktuur waaraan hulle hul kan verbind. As voorbeeld kan verwys word na uitdagings soos die gebrek aan elektrisiteit, die gebrek aan sanitasie, tekorte aan klinieke, onaanvaarbare omgewings om in te woon en 'n ongekontroleerde bevolkingsaanwas. Die gebrek aan dienste is ook groot en baie min dienste word volledig gelewer. Verdere probleme wat opduik, is die versorging van siekes, opleiding, onderwys en opleiding (kyk Anon. 2013c en South Africa 2013).

Dit is inderdaad duidelik dat daar min oplossings in Afrika vir die uitdagings in informele gebiede bestaan. Daar kan aangetoon word dat die uitdagings kritieke punte bereik, en dit moet dus aanvaar word dat daardie uitdagings hanteer moet word. Die artikelouteur het intensief aan al die uitdagings in die gebiede rondom Bloemfontein aandag gegee (Verster 2012). Uit verskeie onderhoude is afgelei dat daar intensiewe aandag aan die uiterste omstandighede waaronder inwoners in hierdie gebiede verkeer, gegee moet word. Vanuit die kwalitatiewe navorsing is afgelei dat armoede die gemeenskap uiters direk raak en dat 'n benadering waar die kerk en die owerhede saam daaraan aandag gee, deur respondente voorgestel word (Verster 2012:40). 'n Gebrek aan voedsel, werkloosheid, lewensomstandighede waar die gebrek aan water en elektrisiteit voorkom, is aangetoon (Verster 2012:34). Daar was 'n positiewe houding teenoor die kerk, waar gevoel is dat die kerk en die owerhede projekte moet begin om die armoede teen te werk (Verster 2012:36-37).

Thabong (2009:8) skryf dat die informele behuisingsgebiede tydbomme is wat dreig om te ontplof weens die ongekende groei van hierdie gebiede en die feit dat meer en meer mense in enkele strukture gehuisves moet word. Talle van die strukture ontvlam en groot gebiede brand af (Eliseev 2007:1). Madlinkomo(2006:5)duiaandatuitersteweersomstandighede die mense tot die uiterste beproef. Battersby (2002:9) vind getuienis dat daar in informele behuisingsgebiede 'n groot voorkoms van MIV/Vigs is. Die eksponensiële groei van die gemeenskappe stel ongelooflike eise aan die gemeenskap, die regering en die kerk (Anon. 2013a).

Sekhaulelo (2014) verwys na die groot uitdaging van werkloosheid wat tot armoede, honger en 'n gebrek aan selfvertroue lei. Hierdie toestand lei weer tot afguns en 'n verset teen die gemeenskap wat, volgens die werkloses, die sisteme in plek plaas wat tot hulle werkloosheid gelei het. Hele gemeenskappe word soms daardeur geraak en dit bring groot spanning in gesinne mee. Baie mense is nie opgelei om in die behoeftes van die arbeidsmark te voorsien nie, wat tot verdere minderwaardigheid aanleiding gee. Dit stel die staat voor groot uitdagings (Anon. 2013b:9).

Daar is talle gevalle waar groot onsekerheid bestaan oor die wyse waarop die plaaslike regering vir die gemeenskap sorg. Gevalle is juis al aangemeld waar die gemeenskap uiters ontevrede is omdat die leiers wat die plaaslike gemeenskap moet dien, net ter wille van hulself optree. Die opgradering van die gemeenskappe stel dus uiterste eise aan die regering (Anon. 2014).

Die probleme wat die informele gebiede bied, is dus ongelooflik groot. Ten spyte daarvan kom daar tog 'n lewendige gemeeskapslewe voor en sien mense na mekaar om. Dit beteken dat daar tog flitse lig in die duistere omstandighede is. Hierdie positiewe benaderings moet uitgebou en beklemtoon word.

Hoe kan die missionale kerk in hierdie gemeenskappe 'n betekenisvolle invloed uitoefen? Die missionale kerk moet in daardie gemeenskappe lewende kerke wees wat nie net op hulleself gerig is nie, maar juis na die gemeenskap uitreik in 'n lewende kerugma, diakonia, kononia en leiturgia. Dit moet belangrike elemente van gesonde ekumenisiteit wees, naamlik waar die kerk nie daarna strewe om net getalle of inkomste te vermeerder nie, maar saam na oplossings in die gemeenskap te soek - dit moet duidelik vertoon en ondersoek word. Die ekumeniese gemeenskap van die verskillende kerke sal ook moet poog om vanuit 'n gesonde benadering na die diepste nood van die mense om te sien.

\section{Missio Dei}

Die begrip missio Dei is tans die heersende beginsel waarvolgens die sending beskryf word (Bosch 1991:390). Daarvolgens stuur God as die Skepper van hemel en aarde sy Seun na die wêreld om die heil van God in sy koninkryk deur te gee. Skreslet (2012:31) wys op die misbruik van hierdie begrip wat nou reeds ' $n$ algemene term in die sending is. Alhoewel die toewyding daaraan soms nie genoegsaam is nie, is dit steeds die heersende begrip betreffende die sending. Die gemeenskap wat deur Christus se bediening tot stand kom, is die kerk, wat self ook 'n gestuurde is. Die missio Dei impliseer dat die sending van God kom. God is die inisieerder van die sending. Daarvolgens is die sending nie 'n aktiwiteit van die kerk nie, maar 'n kenmerk van God self. God is die God van die sending soos Bosch (1991:390) dit duidelik verwoord, naamlik 'to participate in mission is to participate in the movement from God's love towards people, since God is a fountain of sending love'.

Buys en Jansen (2015) vat die begrip missio Dei uitstekend soos volg saam:

- God is besig om ter wille van sy eer

- op grond van Jesus Christus se lyding, dood en opstanding

- deur die Heilige Gees wat die kerk toerus as God se instrumente

- met woorde en dade van liefde en geregtigheid

- mense uit elke volk en taal en nasie bymekaar te maak en te verenig

- om God ewig in 'n nuwe skepping te dien en te aanbid.

Wright (2006:47) toon aan dat die sending te midde van die diversiteit en meervoudigheid van kulture en relasies binne die verbond, die verhouding met God en die mense bepaal. 
De Neui (2007:94) skryf dat die wyse waarop die missio Dei optree in werklikheid 'n misterie is. Die getuienis aangaande God waarin sy wonderbaarlike eienskappe gesien kan word, gaan oor die hele wêreld uit; en nasies en volkere word opgeroep om die heil wat van God kom, te soek. Wat ook van belang is, is dat die missio Dei beteken dat mense in diens geneem word, maar dat hulle diens volkome in Jesus Christus gevind word. Die feit dat God roep en stuur, bring ook 'n groot verandering te weeg.

Wickeri (2004:187) lig uit dat die missio Dei juis die radikale optrede van God in die geskiedenis veronderstel. Daarom word alle denke oor die sending uitgedaag. Daarmee word die hele sendingpoging van die kerk bevraagteken. Daar is ' $n$ beweging van kerkgesentreerde sending na ' $n$ sendinggesentreerde kerk. In hierdie opsig moet egter teen die gedagte gewaak word dat die kerk van minder belang is. Dit is juis die kerk wat die gemeenskap kan bedien. Die sending word egter nie deur die kerk bepaal nie. Die kerk moet juis die sending dien. Wickeri (2004:187) is egter ook van mening dat die missio Dei veel ruimer as die tradisionele sending is. Dit beteken ook dat God in alle kulture werksaam was en is, asook in alle godsdienste. Hierdie ruim begrip van die missio Dei kan beteken dat die unieke betekenis van Jesus se verlossing onderbeklemtoon word. 'n Enger beskouing van die missio Dei met die Christosentriese uitgangspunt is dus meer gewens. Missio Dei berus op die duidelike uitgangspunte in die Nuwe Testament, naamlik dat die heil wat kom direk aan Jesus Christus, die Seun van God, gebind word. Nêrens word dit beter aangedui nie as waar Jesus self in Johannes 20:21-22 vir die dissipels sê: 'Vrede vir julle!' en 'Soos die Vader my gestuur het, stuur ek julle ook'. Daarna het Jesus oor hulle geblaas en gesê: 'Ontvang die Heilige Gees.' Die missio Dei word direk aan Jesus self en die gee van die Heilige Gees deur Hom gekoppel. Barrett (1976:474) stel dit besonder duidelik dat hierdie gebeure die kerk beslissend bepaal: 'The life and mission of the church are meaningless if they are detached from this historical and theological context.' Brown (1966:1036) beklemtoon ook dat die kerk alleen die missio Dei in diens van Jesus Christus self kan uitleef. Von Whalde (2010) sluit hierby aan:

In spite of the present saying's brevity, much is implied, for the disciples being sent is related directly to Jesus's own being sent by the Father, and so evokes all that is said about Jesus as one sent. And so, rather than presenting a distinct and specific model for the disciples, Jesus associates the disciples' sending with his own. (p. 864)

Soos Jesus self tot die heil van mense deur die Vader gestuur is, so word die dissipels ook gestuur om in gehoorsaamheid aan God, diens aan die mense te verrig (Zumstein 2016:759).

Dit is egter veral Bevans en Schroeder (2006) wat aangrypend skryf:

Mission is the basic and most urgent task of the church, not because without human action so many might not reach some kind of fulfilment, but because to be Christian is to become part of God's life and God's vision for the world. (p. 303)
Dit is dus van die uiterste belang om te bepaal dat die sending transendensie beklemtoon. Sending is uit God en wys heen na God. Sending roep op tot 'n lewe met God. Juis omdat God die Transendente is, moet sending Hom verheerlik. Die wesenlike van sending is om te erken dat God wel God is. Hierdie erkenning van die transendensie is noodsaaklik om die korrekte perspektief op die heilbrengende genade van God te behou. Daaruit vloei die erkenning dat die inkarnasie die transendente God naby die mens bring.

\section{Die missionale kerk}

Verkuyl (1979:175) toon aan dat diegene wat sending beoefen die volle koninkryk van God as oriëntasiepunt moet neem. Die volle realiteit van die mens in die wêreld moet benader word. Die klem mag soms op verskillende aspekte val: soms armoede en hongersnood, soms op siekte, rassespanning, uitbuiting, ensovoorts. Die volle boodskap van die evangelie moet egter altyd uitgedra word. Die volle boodskap van God se beloftes en die ware Messias moet verkondig word.

Kakwata (2016) is van mening dat sonde universeel en persoonlik is. Dit is juis die sonde teen God en die medemens wat tot die uiterste armoede van die menigtes in die wêreld, veral in Afrika, gelei het. Die missionale kerk sal daarop moet reageer.

Engelsviken (2003) toon juis aan dat die kerk sentraal in die begrip van die missio Dei staan. Wat God deur die kerk in die missio Dei doen, is deel van die volledige optrede van God in die wêreld:

As I see it, the communication of the good news - in word and deed - is basically the means, the instrument, by which the kingdom of God is coming, by which God fulfils his mission. (p. 485)

Richebacher (2003:604) beklemtoon dat dit wat hy die missio Dei Triunius noem, wel beteken dat Christene hulle geloof nie anders as binne die gemeenskap van die geloof uitleef nie. So word die heling, verlossing en seën van Christus beleef. 'n Unieke gemeenskap van geloof word geskep. Sending vind juis betekenis in die gemeenskap van die geloof van die sondaars wat geregverdig is. Vernuwing kan steeds deur die Heilige Gees kom. Die gemeenskap van geloof kom juis daarin na vore dat die hoop van die koninkryk lewend bly.

Hoe lyk dit dan in die kerk? In hierdie verband het die missionale kerk sterk na vore gekom. Guder (2009:72) beklemtoon dat die kerk se bestaan missionaal moet wees en dat die kerk sodanig moet lewe dat die missionale bestaan in die wêreld sigbaar kan wees. Hy (Guder 2009:72) beskryf die taak van die kerk as die gemeenskappe wat van God se ingrype in die wêreld getuig om die apostoliese roeping uit te leef. Die kerk moet steeds vanuit die apostoliese getuienis die geesvervulde werk van God in die wêreld sigbaar maak.

Hoe moet die kerk dan daar uitsien om waarlik kerk te wees? Buys (2013) beklemtoon enkele sake wat inderdaad van groot belang is en betekenisvol verreken kan word. Daar moet visie 
op die Drie-enige God wees wat sy wonderbare genade aan sondaars bekend maak. Die kerk moet in woorde en in dade deel van God se sending word. 'n Integrale eenheid moet deur die kerk se dienste gehandhaaf word sodat die gemeenskap opgebou kan word en die kerk kan groei. Hy stel die volgende:

Slegs waar die gemeente voluit as liggaam van Christus leef en werklik deur sy liefde gedring word om in 'n gebroke wêreld kanale van sy liefde - deel van God se strome van lewende water - teenoor alle mense te wees, sal die kerk effektief in getalle sowel as in geestelike diepte en godsvrug groei.

Daar moet juis na verhoudings van liefde gestreef word, omdat die kerk uit die liefde tot God leef wat weer die onderlinge liefde tussen mense bepaal (Sundermeier 2003:573). Dit beteken ook dat die kerk geregtigheid en liefde beklemtoon (McPhee 2001:11). Die missionale kerk moet egter ook God se heerskappy oor die hele skepping bevestig (Flemming 2012:164). Mashau (2014) skryf daarom:

The use of the word missional presupposes a radical shift in terms of what churches are doing and should do (missiones ecclesiae) as they participate in the mission of God. It also suggests a radical shift in terms of our understanding of what the church is. Missional churches are presumed to be different from churches which are considered mission-minded.

Die missionale kerk wil vanuit die kern van die sending in God se Naam na die gemeenskap uitreik sodat die gemeenskap self God se heil kan beleef.

Sarisky (2014:262) skryf dat Newbigin se beskouing van die kerk, naamlik as die gemeenskap wat geroepe is en deur God uitgestuur word om die Seun van God se sending in die wêreld uit te voer, opgesom kan word as teken, instrument en voorsmaak ('sign, instrument, and foretaste'). Newbigin (1995) stel dit soos volg:

While Jesus lived on earth, the kingdom of God was present in his person. Now, it is present in the church, not in a triumphalistic sense (as a successful cause) or in a moralistic sense (as right-eous cause), but in the mode of sign, instrument, and foretaste. (bl. 54)

God het die sending begin en ook voorgesit op die wyse waarop Hy steeds sy werk voltooi (Sarisky 2014:267).

In hierdie verband het Hancke ook 'n belangrike bydrae gelewer. Hy verwys daarna dat die missio Dei beklemtoon dat God die een is wat vanuit sy bestaan die kerk roep om by die gemeenskap betrokke te raak en die gemeenskap op 'n bepaalde wyse te rig. Die gemeente moet 'n holistiese, gebalanseerde missionêre verantwoordelikheid, wat op die hele Skrif gebaseer is, vertoon (Hancke 2010:63). Die kerk moet egter as sodanig vanuit die verskillende perspektiewe waartoe die kerk geroep is by die gemeenskap betrokke raak. Die missio Dei bepaal die kerk se missionêre aard. Dit beteken dat die kerk nie lukraak kan besluit waar om betrokke te raak nie, maar dat die totale gemeenskap in die oog gehou moet word (Hancke 2010:110). Dit beteken dat die kerk as kerk steeds in so 'n verband moet bestaan dat dit op verskillende wyses in die gemeenskap betrokke raak. Die kerk kan dus nooit op sigself gekeer wees nie. Die kerk moet na buite uitbeweeg; moet by die gemeenskap daar buite betrokke raak. Hancke vat dit soos volg saam:

In die uitleef van sy missionele karakter is die kerk ' $n$ gemeenskap, 'n dienskneg en 'n boodskapper van God se koninkryk. Die uitleef hiervan vind ook nie sonder slag of stoot plaas nie, want die kerk moet dit doen te midde van ander koninkryke met ander prioriteite wat hom opponeer of ignoreer. Na hierdie vyandige wêreld word die missionele gemeente namens die Koning van die koninkryk as verskilmaker gestuur. (bl. 119)

Bosch (1991:368 e.v.) toon aan dat die kerk juis die kerk met ander moet wees. Teenoor die gedagte dat die kerk die kerk van ander, of vir ander moet wees, is die missionale kerk 'n apokaliptiese gemeenskap van God wat nie slegs op oordeel gerig is nie, maar ook op vergifnis om die ander met God in verhouding te bring. So word die kerk die gemeenskap wat uit die genade van God leef en die genade in die gemeenskap voortdra (Bosch 1991:387). Bevans en Schroeder (2006:299) toon ook aan dat die kerk as volk van God juis naas die ander bestaan om hulle in God se heerlikheid in te bring.

Die vraag is dus of hierdie begrip van die kerk as missionale kerk vanuit die missio Dei, vanuit die stuur van die kerk deur God in die wêreld en vanuit God se ingrype in die wêreld, bepaal kan word. Hoe moet die missionale kerk in meer gevestigde gemeenskappe optree, maar ook juis in gemeenskappe wat nie so gevestig is nie? Daar is sekere aspekte van die missionale kerk wat van groot belang is.

Dissipelskap is in hierdie verband belangrik. Daarom skryf van Gelder en Zscheile (2011):

Discipleship is following Christ into participation in God's mission in the world in the power of the Spirit. This means that it lies at the heart of the missional turn. Since missional church is fundamentally about identity - about being the church developing and deepening the Christian identity of every disciple must be at the forefront of the church's focus. (bl. 148)

Die missionale kerk sal dus 'n kerk moet wees wat volledig aan God die Vader oorgegee leef as die Een wat sy Seun deur die Heilige Gees stuur, sodat die Drie-enige God se volledige heil omvattend in die wêreld sigbaar kan word. Hierdie volledige heil moet op alle terreine aan die gemeenskap gebring word. Dit sluit heil in hierdie wêreld in, maar ook wat die toekoms betref. Dit vind plaas deur die bediening van die kerk in kerugma, diakonia, koinonia, marturia en leiturgia om as mense van God die wonder van God te verkondig, voor te leef en uit te leef.

Die kerk word dus vanuit die verhouding met die Skeppergod gesien, omdat daar in Adam reeds 'n kerk vir die Here op aarde versamel is. Die tweede is die Christologiese diepte daarvan. Die missionale kerk kan nie anders verstaan word as die kerk wat vanuit Jesus Christus totaal vernuwe is nie. Christus het die kerk gekoop omdat Hy die Een is wat die heil vir die kerk volbring. Daarom stuur Hy ook sy kerk in 
die wêreld uit met die roeping om die wêreld na Hom te bring, sodat Hy verheerlik kan word. Die versoening in Christus, waar $\mathrm{Hy}$ as die Een vir die ander die heil en versoening bring, is dus belangrik (2 Kor 5:11-21).

Derdens versamel die Heilige Gees nie alleen die kerk nie, maar Hy rig ook altyd die kerk as missionale kerk vanuit die kerugma, koinonia, diakonia en marturia. Die kerk stuur mense uit in die wêreld, rig mense in die wêreld en bevestig kerugmaties in die wêreld dat God die Koning is en dat Christus die verlosser is deur die Heilige Gees. Die kerk dien deur die diakonia in die wêreld, omdat die kerk die missionale kerk is. Die kerk getuig deur die marturia in die wêreld, want die kerk kan nie anders as om van die heil wat van God in Jesus Christus kom, te getuig nie. In die koinonia bring die kerk mense bymekaar sodat hulle bymekaar kan hoort en die heil van die gemeenskap van geloof wel kan beleef. Die vraag wat nou gevra moet word, is of die missionale kerk en die begrip van die missionale kerk in hierdie verband enige betekenisvolle invloed in ' $n$ informele gemeenskap kan hê.

Van besondere betekenis is Paulus se indrukwekkende uiteensetting in 1 Korintiërs $12-14$ in hierdie verband. Die kerk is die liggaam van Christus. Nêrens anders vind die kerk haar bestaan nie. Onder Christus as Hoof is die kerk die wonderbare gemeenskap wat soos die liggaam 'n eenheid vorm waarin mense God kan dien. Mare (1976) verduidelik soos volg:

Paul now illustrates the diversity and unity of the spiritual gifts by the example of the human body. It is made up of many parts, all of them of importance, and yet the whole body functions as a unit. By the words 'So it is with Christ', he means so it is with Christ's body, the church. That the church, the invisible church, as an organic whole is seen in that every believer, regardless of racial and religious connection (Jew or Greek) or social standing (slave or freeman), has been united by the one Spirit into one spiritual body in baptism. (bl. 264-265)

Thiselton (2006:216) toon aan hoe dit juis beteken dat die liefde in Christus die kerk bepaal, en dat die gelowige nie die medegelowige te na wil kom nie.

Vanuit die erkenning dat die sending ten diepste vanuit die transendensie van God verstaan moet word, en dus steeds Jesus Christus as die een wat van God kom, bely, moet die kerk self die transendente beklemtoon. Sending beteken dus inderdaad nie dat enkele gemeenskapsdienste verrig word nie, maar wel dat die gemeenskap in 'n lewende verhouding met die transendente God gebring word. Van daaruit volg die gemeenskapsdiens en aksies van die missionale kerk.

\section{Totaliteitsbenadering}

Goheen (2014:370 e.v.) wys op die uitdagings van verstedeliking vir die kerk. Inderdaad sal die kerk juis die verstedelikte mens moet bereik om universeel betrokke te wees. Enkele sake kan uitgelig word om aan te dui hoe belangrik stede vir die sending is: die onnoemlike groot aantal mense; kulturele mag en invloed vanuit die stede; die fokuspunt van kerklike betrokkenheid; armoede en sosioekonomiese nood; en die feit dat in sommige gevalle die aantal Christene in stede afneem. Om die stede te bereik, stel hy voor dat'n teologie van sending vir stede ontwikkel word. Daar sal dus oor die evangelieboodskap nagedink moet word, gereflekteer moet word oor die stedelike konteks en kontekstualisering. ' $n$ Toegewyde missionale kerk sal dus juis hier na vore kom (Goheen 2014:370).

Vanuit die beklemtoning van die transendensie en die erkenning daarvan in die missionale kerk, volg die diens aan die gemeenskap.

Swart en De Beer (2014) wys daarop dat kerke in Suid-Afrika sukkel om die gemeenskappe in die stede te verstaan en daarby betrokke te raak. Hulle sukkel ook om die uitdagings te hanteer. Die uitdaging van gevestigde kerke is juis hoe hulle kerkgeboue kan aanwend om armoede te verlig en gemeenskappe te ontwikkel. Ander geloofsgemeenskappe het die uitdaging om by vraagstukke soos kinderontwikkeling, kindersorg- en opvoedingsprogramme, MIV- en Vigs-sorg en hawelose sorg betrokke te raak.

Hoe kan daar egter intensief in die uitdagende informele gemeenskappe rondom stede in Suid-Afrika opgetree word? Mashau (2014) skryf dat die missionale ekklesiologie wat die missio Dei dien, omhels moet word:

Christian mission should be faithful in fulfilling its missionary calling in the city context, working as the 'eyes', 'ears', 'heart', 'hands' and 'feet' of Christ in ministering to the felt needs of city dwellers. Christian mission will therefore be seen as listening to the stories and walking side by side with those on the margins, thereby seeking to gain God's intervention for their life challenges together. Christians should become caring communities in the public square.

In gemeenskappe in informele gebiede kan dit juis na vore kom deurdat die armes self vir mekaar omgee sodat geeneen sonder kos bly nie. Gemeentes moet self die armstes van die armes bemagtig deur hulle in die gemeente op te neem en te versorg. Een keer per maand kan almal wat nog iets oor het, dit kerk toe bring en uitdeel aan hulle wat nog minder het (vgl 2 Kor 8 en 9). Fikkert en Mask (2015:179 e.v.) toon byvoorbeeld aan hoe die kerk by mikrofinansiering betrokke kan raak en so die armstes in gemeenskappe kan bemagtig. Kerke wat self arm is, maar ook arm gemeenskappe, kan hierdeur bemagtig word om selfversorgend te word.

Die werk wat onder gemeenskappe gedoen word, kan aansluiting vind by baie aksies soos Torings van Hoop (www. towersofhope.org) in Bloemfontein, en Ethembeni (www. ethembeni.org) in Kwa-Zulu Natal om juis die kerk te bemagtig om omgee tot groter hoogtes te voer. Spaudazo (www.spaudazo.co.za) is 'n organsisasie in Bloemfontein wat skadunette oprig in gebiede soos Fase 7 in die informele gebiede. Mense word bemagtig om self groente te kweek. So word selfrespek maar ook fisiese selfversorging gekweek. 
Dit is egter belangrik dat die kerk gemeenskappe moet help om fondse reg te bestuur. Opleiding is in hierdie verband van groot belang. Befus (1999:92) toon aan dat goeie bestuur noodsaaklik is om gemeenskape op te bou. Kemper (2014:189) wys weer daarop dat die Heilige Gees juis in die missio Dei teenwoordig is deur die wyse waarop Hy inisieer, onderhou en herstel. Kemper (2014:190) toon verder aan dat heling en heelheid wel ook deur die sending na vore kom waar vrede, geregtigheid en bevryding deur die sending beklemtoon word.

Genesing moet nie aan predikers wat hulleself verryk en mense onder spanning bring, oorgelaat word nie. Deur die oprigting van klinieke kan die kerk juis onder gemeenskappe teenwoordig wees en in die genesingsbediening deel. Waar die kerk nie oor baie middele beskik nie, kan wel veral kleuterskole vanuit die klein kerkies opgerig word.

Majawa (1998:265) verwys na die gevaar dat die opheffing van armoede slegs 'n sekulêre saak van suksesvolle ingrype gemaak kan word. Menslike betrokkenheid kan egter wel liefde en ywer opwek, wat tot 'n meer menslike samelewing kan lei.

Dit is dus duidelik dat die missionale kerk radikaal deur die beklemtoning van transendensie en die diens wat daaruit volg, by die mens in diepe nood betrokke moet raak.

\section{Kerk en gemeenskap}

Miller (1998:122-123) toon aan hoe die Christelike evangelie betekenisvol vir die verstedelike gemeenskap kan wees. In die verstedelikte gebiede is die volgende relevant: die beklemtoning van die waardigheid van elke mens; die liefde van en vir mense om skadelike individualisme teen te werk; geregtigheid soos dit deur die Ou-Testamentiese profete uitgelig is; die kerk se besondere bemiddelende rol in gemeenskappe waar daar groot behoefte daaraan bestaan; en die sinvolle oordra van ware godsdiens.

Kehrein (1995:179) beklemtoon dat die kerk alleen die ontwikkeling in arm gemeenskappe kan dien indien plaaslike kerke in verhouding met ander kerke tree deur die beklemtoning van gedeelde Christelike waardes en versoening, om saam te werk tot die opbou van die gemeenskap. Ook Padilla (2004:296-297) maak dit duidelik dat die kerk wat gemeenskappe in nood wil dien, van uitsluiting na solidariteit moet beweeg en dat die Gekruisigde juis in hierdie verband gedien moet word.

Die kerk sal in die lig van die voorafgaande in die eerste plek vanuit die Kerugma die mense in informelebehuisingsgebiede moet inspireer tot nuwe hoop. Die boodskap van ware verlossing in Jesus Christus is die boodskap wat wel die ware hoop bring. Vanuit die diepe nood van sonde kom die heil soos aangedui deur Paulus in Romeine 3. Hoop is sentraal in die benadering tot die mense in sulke gemeenskappe en dit sal uit die aard van die saak ontsettend belangrik wees om mense in daardie gemeenskappe te bedien.
Die tweede belangrike punt wat na vore kom, is dat daar 'n dienende gemeenskap moet wees. In hierdie verband moet ernstige kritiek uitgespreek word teen kerke wat geweldige wins toon deur die gemeenskap van mense in hulle diepste nood uit te buit deur al hoe meer van hulle te verwag, geweldige uitdagings van hulle te vra en groot invloed op hulle uit te oefen. Nie alleen word tente opgerig nie, maar daardie tente is dikwels dié van predikers wat probeer om vir hulself soveel as moontlik uit die gemeenskap te verkry. Dit moet op 'n bepaalde manier hanteer word. Die wyse waarop die kerk betrokke moet wees, is dat dit 'n kerk van diens moet wees; 'n kerk van afhanklikheid van die Here moet wees. In ekumeniese verband sal kerke mekaar ook moet teregwys wanneer dit blyk dat hulle mense uitbuit. Die welvaartskerke sal in hierdie verband deeglik moet besin. Selfs onder inwoners van die informele gebiede is daar baie wat hulle laaste sente sal gee vir welvaartspredikers met die hoop dat die beloftes van rykdom sal realiseer. Dikwels lei dit net tot groter armoede.

Die begrip van gasvryheid is in hierdie verband van groot belang. Pocock et al. (2005:68) toon aan dat die kerk die waardigheid van mense moet erken. Dit is van groot belang dat mense wat ontwortel is juis hartlik in die kerk ontvang moet word en dat hulle ruimte vir menswaardigheid in die kerk moet ontvang. Volgens Pocock et al. word dit deur die inkarnasie van Jesus sterk beklemtoon.

Die derde aspek wat na vore kom, is dat daar veral na die jeug omgesien moet word. Die jeug in hierdie gemeenskappe is onder geweldige druk vanweë die probleme met opvoeding asook die verval in dwelmmisbruik en misdaad. Die kerk kan aan verslaafdes ruimte bied om te herstel en aan die jeug aktiwiteite aanbied om hulle van die strate af en uit die dranksale te kry. Daar is voorbeelde waar blaasorkeste en klassieke musiekopleiding die jeug bemagtig om 'n nuwe lewe te begin. Daarom is dit ook belangrik dat die kerk na hulle sal uitreik.

'n Missionale kerk beteken dat mense vir mekaar omgee en dat hulle mekaar ondersteun. Daar moet as 't ware 'n nuwe gemeenskap geskep word. Die missionale kerk moet 'n nuwe gemeenskap in die informele gebied word, waar mense in ' $n$ bepaalde verhouding tot mekaar kan staan en mekaar kan opbou.

Sekhaulelo (2014) toon aan dat die kerk die sigbare uitrukking van die koninkryk van God moet wees,veral teenoor hulle wat daarteen rebelleer. Daar moet veral versoening tussen al die lidmate van al die sosiale, etniese en ekonomiese groepe wees. Nie alleen moet daar binne die kerk aanduidings van armoedeverligting vir hulle wees nie, maar ook vir mense buite die kerk.

Die missionale kerk in die informele behuisingsgebiede moet dus vanuit die nuwe verhouding met God die volle menslikheid beklemtoon. In hierdie verband toon Newbigin (1989:227 e.v.) aan dat transendensie én betrokkenheid by 
mense steeds essensieel is en hy lig die volgende ses belangrike kenmerke in die gemeenskap van geloof uit:

Dit moet 'n gemeenskap van lof aan God wees.

Dit moet 'n gemeenskap wees wat die Waarheid dien.

Dit moet ' $n$ gemeenskap wees wat nie vir hulleself lewe nie, maar vir ander.

Dit moet 'n gemeenskap wees waar die lidmate die priesterskap van die lewe bedien.

Dit moet ' $n$ gemeenskap met gemeenskaplike verantwoordelikheid wees.

Dit moet 'n gemeenskap van hoop wees.

In die informele gemeenskappe sal die lof aan God juis in die kerke wat in die gemeenskappe voorkom na vore moet kom. Te midde van uiterste bedreigings sal die missionale kerk juis onder daardie omstandighede nog eer en lof aan God bring, wat mense kan bemagtig, die omstandighede kan verander en hoop vir die mense skep.

Hier kom leiturgia ter sprake. Die erediens van die kerk bemagtig mense om ook in die erediens van die lewe die wonder van God te besing. Wanneer die waarheid gedien word, sal die kerk ook die valshede en misbruike van die regerings aandui. Die kerk sal al meer vir ander moet lewe. Uitbuiting, ook deur die kerk, word as onaanvaarbaar beskou. Die kerk sal juis moet sorg en nie uitbuit nie. As priester sal die kerk die siekes en swakkes te hulp kom. Verpleging en sorg sal belangrik wees. Daar sal gemeenskaplike verantwoordelikheid geneem moet word vir die spanningsveld van armoede en werkloosheid. In ekumeniese verband sal juis saamgewerk kan word om tuisverpleegsters op te lei om veral na Vigs-pasiënte om te sien. Die kerk en staat sal moet saamwerk en die kerk sal leiding moet gee. Kritzinger (2014) verduidelik dit soos volg:

In order to do this with credibility, a series of interdisciplinary think tanks and task teams need to be established, each focusing on one of the 'powers', composed of theologians, economists, lawyers, engineers, etc. to develop informed positions and plans for public life. Through regular workshops they could develop an informed and credible public theology and communicate their insights in significant ways to the city through the media, including the social media.

Lof aan God sal ook met hoop gevul moet word. So sal die kerk die volle boodskap van heil bring. Dit gaan dan daarom om nie oneties op te tree nie. Die kerk moet deur 'n gesindheid van opregte liefde deur die Heilige Gees gerig word (Lazenby \& Niemandt 2014).

Nihinlola (2010) kom tot die volgende gevolgtrekking:

The African church is poor, but she has no excuse to abandon the Great Commission. The church in Africa has grown to the point of taking the responsibility to evangelise the continent. (bl. 109)

\section{Slot}

Vanuit die missio Dei moet die missionale kerk ook in informele gebiede 'n lewende kerk wees. Dit is alleen moontlik indien die kerk vanuit die Hoofskap van Christus lewe. Transendensie onder haglike omstandighede moet ook beklemtoon word. Vanuit die erkenning van God se heerlikheid volg die radikale betrokkenheid by die mens in nood. Alleen in die drie-enige God kan mense in hulle diepste nood heil vind.

\section{Erkenning Mededingende belange}

Die outeur verklaar dat sy geen finansiële of persoonlike verbintenis het met enige party wat haar nadelig of voordelig kon beïnloed het in die skryf van hierdie artikel nie.

\section{Literatuurverwysings}

Anon., 2013a, 'Informal settlements a problem: Sexwale', viewed 14 October 2016, from http://www.iol.co.za/news/politics/informal-settlements-a-problemsexwale-1488954

Anon., 2013b, 'State fails to deal with unemployment', Sowetan, 9 May, 2013, p. 3.

Anon., 2013c, 'Tough-living-for-the-people-of-zuzokuhle-informal-settlement', viewed 14 October 2016, from https://www.health-e.org.za/2013

Anon., 2014, 'Upgrading informal settlements is a complex challenge', viewed 14 October 2016, from http://mg.co.za/article/2014-06-26-upgrading-informalsettlements-is-a-complex-challenge

Barrett, C.K., 1976, The Gospel according to St John, SPCK, London.

Battersby, J., 2002, 'Informal settlements breed HIV', Star, 6 December, p. 9.

Befus, D.R., 1999, 'Discovering a role in God's provision', in B.L. Myers, Working with the poor: New insights and learnings from development practitioners, pp. 81-93, World Vision, Monrovia.

Bevans, S.B. \& Schroeder, R.P., 2006, Constants in context: A theology of mission for today, Orbis, Maryknoll.

Bosch, D.J., 1991, Transforming mission: Paradigm shifts in theology of mission, Orbis, Maryknoll.

Brown, R.E., 1966, The Gospel according to John XIII-XXI, Chapman, London.

Buys, P.J., 2013, 'Strome van lewende water: Nuwe Testamentiese perspektiewe op die missionêre karakter van die kerk', In die Skriflig/In Luce Verbi 47(1), Art. \#97, $11 \mathrm{p}$, besoek op 7 September 2016, by https://doi.org/10.4102/ids.v47i1.97

Buys, P.J. \& Jansen, A., 2015, “"Met hart en mond en hande”: Die integrale bediening van Woord en daad volgens ' $n$ missio Dei perspektief', In die Skriflig 49(1), Art. \#1883, 12 p., besoek op 7 September 2016, by https://doi.org/10.4102/ids. v49i1.1883

De Neui, P.H., 2007, 'Christian communitas in the missio Dei: Living faithfully in the tension between cultural osmosis and alienation', Ex Auditu 23, 92-107, viewed 7 September 2016, from ATLA Religion Database with ATLASerials, EBSCOhost.

Eliseev, A., 2007, 'Squatter settlements up in flames', Star, 10 July, p. 1.

Engelsviken, T., 2003, 'Missio Dei: The understanding and misunderstanding of a theological concept in European churches and missiology', International Review of Mission 92(367), 481-497, viewed 7 September 2016, from ATLA Religion Database with ATLASerials, EBSCOhost.

Fikkert, B. \& Mask, R., 2015, From dependence to dignity: How to alleviate poverty through church-centred microfinance, Zondervan, Grand Rapids.

Flemming, D., 2012, 'Revelation and the missio Dei: Toward a missional reading of the apocalypse', Journal of Theological Interpretation 6(2), 161-177, viewed 2 September 2016, from ATLA Religion Database with ATLASerials, EBSCOhost.

Goheen, M.W., 2014, Introducing Christian mission today: Scripture, history and issues, IVP Academic, Downers Grove.

Guder, D.L., 2009, 'Missio Dei: Integrating theological formation for apostolic vocation', Missiology 37(1), 63-74, viewed 7 September 2016, from ATLA Religion Database with ATLASerials, EBSCOhost.

Hancke, F., 2010, Ons is die plan: Die geheim van verskilmakende gemeentes, ISWEN, Pretoria.

Kakwata, F., 2016, 'A theology of sin related to poverty', In die Skriflig 50(1), a2033, viewed 7 September 2016, from https://doi.org/10.4102/ids.v50i1.2033

Kehrein, G., 1995, 'The local church and Christian community development', in J.M. Perkins (ed.), Restoring at-risk communities: Doing it together and doing it right, pp. 163-180, Baker, Grand Rapids.

Kemper, T., 2014, 'The missio Dei in contemporary context', International Bulletin of Missionary Research 38(4), 188-190, viewed 2 September 2016, from ATLA Religion Database with ATLASerials, EBSCOhost.

Kritzinger, J.N.J., 2014, 'Concrete spirituality', HTS Teologiese Studies/Theological Studies 70(3), Art. \#2782, 12 p., viewed 7 September 2016, from https://doi. org $/ 10.4102 /$ hts.v70i3.2782

Lazenby, M.J. \& Niemandt, C.J.P., 2014, 'Missionale kerkwees en die elektroniese sosiale media', In die Skriflig 48(1), Art. \#1770, 6 p., besoek op 2 September 2016 by https://doi.org/10.4102/ids.v48i1.1770

Madlinkomo, X., 2006, 'Plea to help shack dwellers beat the chill', Cape Times, 17 August, p. 5. 
Majawa, C.A., 1998, 'The church's prophetic role in the struggle against poverty in Africa', Afer 40(5-6), 258-270, viewed 27 September 2016, from ATLA Religion Database with ATLASerials, EBSCOhost.

Mare, W.H., 1976, '1 Corinthians', in F.E. Gaebelein (ed.), The Expositor's Bible commentary: Romans through Galatians (vol. 10), pp. 254-285 Zondervan, Grand Rapids.

Mashau, T.D., 2014, 'Reimagining mission in the public square: Engaging hills and valleys in the African City of Tshwane', HTS Teologiese Studies/Theological Studies 70(3), Art. \#2774, 11 p., viewed 7 September 2016, from https://doi.org/10.4102/ hts.v70i3.2774

McPhee, A., 2001, 'The missio Dei and the transformation of the church', Vision (Winnipeg, Man.) 2(2), 6-12, viewed 7 September 2016, from ATLA Religion Database with ATLASerials, EBSCOhost

Miller, D.E., 1998, 'The church in the city: A mediating and catalytic agent for socia change', in T.

Yamamori, B.L. Myers \& K.L Luscombe, Serving with the urban poor, pp. 119-127, Marc, Monrovia.

Newbigin, L., 1989, The gospel in a pluralist society, Eerdmans, Grand Rapids.

Newbigin, L., 1995, The open secret: An introduction to the theology of mission, rev. edn., Eerdmans, Grand Rapids.

Nihinlola, E., 2010, 'Poverty and prospects of Christian mission in Africa: A theological viewpoint', Ogbomoso Journal of Theology 15(2), 99-110, viewed 27 September 2016, from ATLA Religion Database with ATLASerials, EBSCOhost

Padilla, C.R. 2004, 'Vignettes of a servant church', in T. Yamamori \& C.R. Padilla (eds.), The local church, agent of transformation: An ecclesiology for integral mission, $\mathrm{pp}$. 289-300, Kairos, Buenos Aires.

Pocock, M., Van Rheenen, G. \& McConnell, D., 2005, The changing face of world missions: Engaging contemporary issues and trends, Baker Academic, Grand Rapids.

Richebacher, W., 2003, 'Missio Dei: The basis of mission theology or a wrong path?' International Review of Mission 92(367), 588-605, viewed 7 September 2016 from ATLA Religion Database with ATLASerials, EBSCOhost

Sarisky, D., 2014, 'The meaning of the missio Dei: Reflections on Lesslie Newbigin's proposal that mission is of the essence of the church', Missiology 42(3), 257-270, viewed 2 September 2016, from ATLA Religion Database with ATLASerials, EBSCOhos
Sekhaulelo, M.A., 2014, 'Reformed churches in South Africa's strategies for poverty reduction in urban communities', In die Skriflig 48(1), Art. \#1788, 10 p., viewed 7 September 2016, from https://doi.org/10.4102/ids.v48i1.1788

Skreslet, S.H., 2012, Comprehending mission: The questions, methods, themes, problems, and prospects of missiology, Orbis, Maryknoll.

South Africa, Department of Human Settlement, 2013, The National Upgrading Support Programme: Part 1: Understanding your informal settlement, viewed 14 Oktober 2016, from http://www.upgradingsupport.org/content/page/part-1understanding-your-informal-settlements

Sundermeier, T., 2003, 'Missio Dei today: On the identity of Christian mission', International Review of Mission 92(367), 560-578, viewed 7 September 2016, from ATLA Religion Database with ATLASerials, EBSCOhost

Swart, I. \& De Beer, S., 2014, 'Doing urban public theology in South Africa: Introducing a new agenda', HTS Teologiese Studies/Theological Studies 70(3), Art.\#2811, 14 p., viewed 7 September 2016, from https://doi.org/10.4102/hts.v70i3.2811

Thabong, M., 2009, 'Informal settlements a time bomb', Business Day, 2 September, p. 8.

Thiselton, A.C., 2006, 1 Corinthians: A shorter exegetical and pastoral commentary, Eerdmans, Grand Rapids.

Van Gelder, C. \& Zscheile, D.J., 2011, The missional church in perspective: Mapping trends and shaping the conversation, Baker Academic, Grand Rapids.

Verkuyl, J., 1979, 'The kingdom of God as the goal of the missio Dei', International Review of Mission 68(270), 168-175, viewed 7 September 2016, from ATLA Religion Database with ATLASerials, EBSCOhost

Verster, P., 2012, New hope for the poor: A perspective on the church in informal settlements in Africa, Sun Press, Bloemfontein.

Von Wahlde, U.C., 2010, Commentary on the Gospel of John: The Gospel and letters of John, Eerdmans, Grand Rapids. (Eerdmans critical commentary, vol. 2).

Wickeri, P.L., 2004, 'Mission from the margins: The missio Dei in the crisis of world Christianity', International Review of Mission 93(369), 182-198, 7 September 2016, from ATLA Religion Database with ATLASerials, EBSCOhost.

Wright, C.J.H., 2006, The mission of God: Unlocking the Bible's grand narrative, InterVarsity, Nottingham.

Zumstein, J., 2016, Das Johannesevangelium, Vandenhoeck \& Ruprecht, Göttingen. (Meyers kritisch-exegetischer Kommentar über das Neue Testament). 